\title{
A SURVEY ON THE ADOPTION OF LEAN PRACTICES IN INDIAN MANUFACTURING SECTOR
}

\author{
Singh M.P \\ Professor, Jagannath University, Jaipur, India \\ Ramphool Meena
}

Research Scholar, Jagannath University, Jaipur, India

Avinash Panwar

Lecturer, Govt. R. C. Khaitan Polytechnic College, Jaipur, India

\begin{abstract}
Lean manufacturing is a production strategy to eliminate waste and nonvalue added activities in a process while maximizing the value added tasks as required by the customer. The adoption of lean approaches in India has been much slower. Indian industries find many challenges in adopting lean thinking as a standard manufacturing practice. it has been proved from certain studies that implementation of lean thinking in manufacturing sector is highly useful in terms of elimination of waste, proper utilization of workspace, proper organization of workforce, to reduce inventory, to increase productivity and to increase customer satisfaction. This study will guide the Indian industries in selecting lean tools based on the characteristics and expected wastes. The current study comprise of a survey of Indian manufacturing industries. The survey will be useful to explore the current status of lean initiations in Indian manufacturing industries and to prioritize lean practices which are highly useful.
\end{abstract}

Key words: Lean manufacturing, lean practices, India, Indian industries, Survey

Cite this Article: Singh M.P., Ramphool Meena and Avinash Panwar, A Survey on the Adoption of Lean Practices in Indian Manufacturing Sector, International Journal of Industrial Engineering Research and Development, 7(2), 2016, pp. 52-62.

https://iaeme.com/Home/issue/IJIERD?Volume=7\&Issue=2 


\section{INTRODUCTION}

In the current era of globalization, to compete and to stay alive in the market, adoption of new tools and techniques to produce goods is mandatory. The most daunting issue faced by manufacturers today is how to deliver their products or materials quickly at low cost and good quality, and the Indian manufacturing industries are not an exception. According to Ghosh (2013), in the era of globalization and open market policies, Indian manufacturing companies are also feeling the heat of competition. Competition has intensified across all sectors whether it is service sector, discrete manufacturing or process manufacturing.

Manufacturing sector of India contributes considerably to the gross domestic product (GDP) of the country. It accounted for nearly 17\% of the GDP in financial year 2012 (IBEF, 2012). Therefore, considering the importance of role of manufacturing industries in Indian economy, industrial growth and significant contribution to GDP, it is vital for manufacturers of India to strive for operational excellence by adopting world-class practices and restructuring operations to remain globally competitive and to expand profits and productivity. Today Indian manufacturing industry is facing an entirely changed competitive scenario than the past.

One challenge for Indian manufacturing industry is to improve the manufacturing efficiency and supply chain performance (Jaiganesh and Sudhahar, 2013). Inventory turns in Indian manufacturing industries is considerably low and therefore, working capital ties up for longer periods in this sector. To improve quality is also a prominent challenge for the manufacturing industries of India (Poongothai and Arul, 2011; Kumar et al. 2015). Indian manufacturing industries have not adopted advance manufacturing technology to a significant level (Dangayach and Deshmukh, 2003, Seth et al., 2008). Therefore, equipment related problems such as; high energy consumption, high reworks and rejections, frequent breakdowns, high accidents rates and high pollution are common in Indian industries (Dogra et al., 2011).

Adoption of lean manufacturing in India has been started very recently. Hence, the status of lean implementation in India is still ambiguous. Therefore, it is uncertain whether manufacturing industries in India are enthusiastic about implementation of lean, or not. Comprehensive literature search confirms that until now only limited attempts have been made to investigate the status of lean manufacturing in Indian manufacturing industries. This study is the first attempt to fill this gap in research and will examine various aspects of implementation of lean manufacturing in manufacturing sector of India.

The major contribution of this research is in-depth investigation of the status of lean implementation in Indian manufacturing industries and to remove the ambiguity about usefulness of lean concepts for Indian manufacturing industries. This research has attempted to address the issues pertaining to embark lean initiations in Indian manufacturing industry. The survey results will produce an overall picture of lean initiations in Indian industries including most useful lean tools and techniques. The eventual goal of this research is to create opportunities for industrial managers and researchers to improve the overall efficiency of the Indian manufacturing industry by application of lean initiations. This will not only help the managers to plan strategies for the adoption of lean but will also remove the scepticism about adoption of lean.

The rest of the paper is organised as follow: section 2 throw light on literature review of lean and its adoption in Indian manufacturing industries. Section 3 presents 
the research methodology used in this work. Results are demonstrated in section 4 and finally this paper is concluded in the last section.

\section{LITERATURE REVIEW}

Lean thinking was first described in 1990's seminal book called "The Machine That Changed the World: The Story of Lean Production". This book describes the changes in automobile manufacturing from craft production to mass production to lean production. The book illustrates the findings of a key research project carried out by the Massachusetts Institute of Technology which investigated productivity and management practices in the world motor industry. The international motor vehicle programme (IMVP) which involved 52 vehicle assembly plants in 14 different countries around the world, was a five-year, $\$ 5$ million programme.

Although, lean is primarily applied in 'high volume, low variety' discrete industry [9-14], researchers support universal applicability of lean concepts. Proponents of lean thinking claim that lean can be implemented in a wide range of industries operating under diverse environments [12]. The main idea is to minimize wastes or muda (the Japanese's word for waste) in order to increase the efficiency of production system. This means eliminating over production and inventory, unnecessary movement of material, waiting and delays, over processing, unneeded worker motion, and the defects. Ref. [12] describes 7 classical wastes in a production system.

At operational level can a collection of lean tools and techniques are required to facilitating the actions required to achieve the objectives directed by different lean principles [15]. For example, lean practices such a value stream mapping (VSM), 5S, total productive maintenance (TPM), visual control, work standardization and mistake proofing help to eliminate wastes, whereas Kanban, pull production, and production levelling are responsible for aligning production with demand. Lean practices such as kaizen, job rotation, and cross functional teams contribute to continuous improvements with constructive involvement of workers. A wide range of lean practices can be found in the extant literature [12,16, and 17].

Table 1 lists previous studies carried out in context to lean implementation in manufacturing industries in India. Ref. [5, 18-22] have attempted to study the implementation of lean manufacturing in certain process industries in India and illustrated that 'lean' can result in numerous benefits.

Table 1: Previous Studies Regarding Lean Implementation in Indian Industries

\begin{tabular}{|c|l|l|l|}
\hline Literature & \multicolumn{1}{|c|}{$\begin{array}{c}\text { Type of } \\
\text { process } \\
\text { industry }\end{array}$} & $\begin{array}{c}\text { Type of } \\
\text { study }\end{array}$ & \multicolumn{1}{|c|}{ Major findings } \\
\hline$[18]$ & Pharmaceutical & Case study & $\begin{array}{l}\text { Integrated production planning } \\
\text { system was helpful to implement lean } \\
\text { concepts in pharmaceutical firm. }\end{array}$ \\
\hline$[19]$ & Steel & Case study & $\begin{array}{l}\text { Application of JIT in purchasing } \\
\text { resulted in considerable cost savings. }\end{array}$ \\
\hline$[20]$ & Steel & Case study & $\begin{array}{l}\text { Applying JIT production resulted in } \\
\text { release of working capital and } \\
\text { decrease in inventory. }\end{array}$ \\
\hline$[23]$ & $\begin{array}{l}29 \text { continuous } \\
\text { manufacturing }\end{array}$ & Survey & $\begin{array}{l}\text { Most important lean tools are TPM, } \\
\text { 'automatic line stoppage', VSM, }\end{array}$ \\
\hline
\end{tabular}




\begin{tabular}{|c|c|c|c|}
\hline & $\begin{array}{l}\text { industries in } \\
\text { India }\end{array}$ & & $\begin{array}{l}\text { 'workplace organisation' and 'visual } \\
\text { control'. Least important lean } \\
\text { practices are 'work standardisation', } \\
\text { 'multipurpose handling' and takt time. } \\
\text { Continuous process industries } \\
\text { perceive higher benefits than discrete } \\
\text { industries from lean manufacturing. } \\
\text { Lack of management support is most } \\
\text { prevailing problem in implementing } \\
\text { lean. }\end{array}$ \\
\hline [7] & $\begin{array}{l}\text { comprising } 37 \\
\text { respondents } \\
\text { from edible oil } \\
\text { industry } \\
\end{array}$ & Survey & $\begin{array}{l}\text { Used value stream mapping and } \\
\text { proved that there exist several non } \\
\text { value added activities in the supply } \\
\text { chain of edible oil industry. }\end{array}$ \\
\hline [21] & Biscuit & Case study & $\begin{array}{l}\text { Used value stream mapping and } \\
\text { identified several wastes in the } \\
\text { manufacturing of biscuits. }\end{array}$ \\
\hline [24] & $\begin{array}{l}127 \\
\text { manufacturing } \\
\text { industries }\end{array}$ & Survey & $\begin{array}{l}\text { Major reasons of lean implementation } \\
\text { in Indian manufacturing industries } \\
\text { included reduction of delivery time, } \\
\text { reduction in cost, enhancing range of } \\
\text { products and due to stiff competition. }\end{array}$ \\
\hline$[1]$ & $\begin{array}{l}9 \\
\text { manufacturing } \\
\text { industries }\end{array}$ & Survey & $\begin{array}{l}\text { Although, the concept of lean is new } \\
\text { for Indian industries, still several } \\
\text { Indian companies are at advanced } \\
\text { level of lean implementation, and by } \\
\text { implementing lean they have } \\
\text { achieved better operational } \\
\text { performance. }\end{array}$ \\
\hline [24] & $\begin{array}{l}31 \text { large } \\
\text { manufacturing } \\
\text { industries }\end{array}$ & Survey & $\begin{array}{l}\text { TPM, continuous improvements and } \\
\text { inventory reduction are primarily } \\
\text { used lean practices in Indian } \\
\text { manufacturing industries. Reduction } \\
\text { in cost and wastes are the major } \\
\text { benefits of lean implementation, } \\
\text { while 'lack of understanding', lack of } \\
\text { top management support' and } \\
\text { 'financial benefits not recognized' are } \\
\text { the major obstacles while } \\
\text { implementing lean. }\end{array}$ \\
\hline [26] & Process & Survey & $\begin{array}{l}\text { Level of lean implementation in } \\
\text { Indian process industries is very low. } \\
\text { Reasons of not implementing lean } \\
\text { include unfamiliarity with lean, lack } \\
\text { of skills and education, and } \\
\text { uncertainty about benefits. The major } \\
\text { lean tools implemented in Indian } \\
\text { process industries are TPM, 5S, work } \\
\text { standardization, SPC and visual } \\
\text { control. }\end{array}$ \\
\hline
\end{tabular}


Ref. [21] applied value stream mapping in a biscuit manufacturing plant and found that application of lean manufacturing resulted in increase in quality, decrease in inventory, increase in timely deliveries, better utilization of space and equipments and reduction in lead time.

Ref. [20] applied some tools of lean manufacturing in a steel manufacturing unit in India and found a reduction in production cost by $8 \%$ and a reduction in lead-time by $50 \%$. Ref. [19] studied the implementation of JIT purchasing in a steel plant in Indian and found that the introduction of this concept resulted in considerable cost savings. Ref. [23] attempted to investigate status of implementation lean tools in India through a survey of 29 continuous manufacturing industries. Authors found that most important lean tools for process industries are TPM, 'automatic line stoppage', VSM, 'workplace organisation' and 'visual control'. Least important lean practices are 'work standardisation', 'multipurpose handling' and takt time. Continuous process industries perceive higher benefits than discrete industries from lean manufacturing and lack of management support is most prevailing problem in implementing lean.

The extant literature regarding lean implementation in India is dominated by case studies [19-21]. These case studies provided only case specific results. These results cannot be generalized. Existing literature provide only a few evidence of empirical research regarding lean implementation in Indian manufacturing industries. Furthermore, existing studies provide industry specific results such as ref. [26] for Indian process industries,

\section{RESEARCH METHODOLOGY}

The main objective of this report is to prioritizing lean practices for Indian industries. To achieve this, data was collected via a questionnaire survey. The survey method is the best data collection technique as it enables us to gather a larger amount of data and information from target respondents within a short period of time.

Survey methodology stresses on quantitative analysis. The focus of the survey is on questions including who, what, where, how much and how many. However, survey method is criticized for its limitation of inability to capture the particulars needed to gain in depth understanding of the mechanics and the causes rooted in the interested processes. Survey approach refers to gathering data in the form of replies to relevant questions from large number of organizations. Data is collected through several means including, telephone interviews, mail questionnaires, or from published information [27].

On the basis of literature review, the questionnaire was formulated. The questionnaire consists four sections

- General information of organisation

- Reason of implementing lean practices

- Reason of not implementing lean

- Lean practices in Indian industries

The target of the study has been the industries operational in western part of India. A structured questionnaire was designed and it was sent to two practitioner and two academicians. Based on the initial feedback received from a pilot questionnaire and subsequent personal interviews held with academicians the final questionnaire was designed. The validation of the questionnaire was done by two managerial persons from major industries one from forging and the other from an automobile sector with 
extensive experience on lean implementation in India. The questionnaire was also pretested by two academicians with an extensive experience in academia and industry.

A sample of 500 companies was taken from industrial directory (2015) and directory of ISO: 9001 certified industries in India. Primarily, postal survey method was used to administer the questionnaire. Questionnaire was mailed to the target firms. The mail had the invitation letter to participate in survey and the lean assessment questionnaire. Invitation letter contained a brief discussion of lean manufacturing and the need of present study, and also the promise to keep anonymity. Telephonic conversations were also undertaken to get consent of the target respondents and to ensure that they have received the questionnaire. It was observed that initially the response rate was low in-spite of repeated reminders. Hence, it was decided to search other means to increase response rate. A few responses were collected through conducting face to face interviews. In some instances, responses were collected through third party channels. These efforts helped, and the response rate increased. To increase the response rate further, emails were sent, followed by a telephonic request for reply. The questionnaire was addressed to higher executives who were responsible for production. Finally, 92 responses received.

It is essential to measure the reliability of the instrument when the variables developed from summated scale are used as predictor components in objective models [28]. In other words, a measuring instrument should provide consistent results, and for it, test of reliability is carried out. Reliability analysis of a questionnaire establishes its ability to yield consistent results. In present study reliability was assessed through internal consistency, which is the degree of inter correlation among the items which build a scale [29]. Cronbach's alpha (reliability coefficient) was used to measure internal consistency [30].Variables having value of alpha more than 0.60 were considered to be highly reliable.

\section{RESULTS AND DISCUSSIONS}

We used Google form to create and store the survey. This enabled us to provide an online survey link to potential respondents. Initial emails were sent to 500 Indian industries. In the email, a general description of the research project, its purpose, and the URL link to the survey was provided. Follow-up emails were sent to these target industries after 2 weeks to remind the respondents to finish the questionnaire. Finally, a total of 92 responses were obtained. As a result, the response rate was $18.4 \%$.

Out of 92 respondents $59(64 \%)$ answered that they are familiar with concept of lean manufacturing. $33(36 \%)$ respondents denied that they are familiar with lean manufacturing. When explained the concept of lean manufacturing and then asked if they think lean practices are useful $71(77 \%)$ respondents replied that they think lean is useful for manufacturing industries in India. However, 21 (23\%) respondents denied that lean is useful.

To identify the important reasons of implementing and not implementing lean in Indian industries, a scale containing eight items was developed after a comprehensive literature review. Respondents were asked to rate the reasons of implementing lean on a five point Likert scale. The rankings of reasons of implementing and not implementing lean are shown in table 2 and 3 respectively. 
A Survey on the Adoption of Lean Practices in Indian Manufacturing Sector

Table 2: Ranking of Reasons of Implementing Lean

\begin{tabular}{|l|c|c|c|}
\hline \multicolumn{1}{|c|}{ Reasons of Implementing Lean } & Rank & Mean & $\begin{array}{c}\text { Std. } \\
\text { Deviation }\end{array}$ \\
\hline To improve quality & 1 & 4.15 & 1.005 \\
\hline To increase customer satisfaction & 2 & 3.86 & 1.256 \\
\hline Elimination of wastes & 3 & 3.74 & 1.254 \\
\hline To decrease production costs & 4 & 3.72 & 1.523 \\
\hline To increase demand management and efficiency & 5 & 3.08 & 1.365 \\
\hline To increase utilization of space and equipment & 6 & 2.89 & 1.524 \\
\hline To increase supply chain efficiency & 7 & 2.66 & 1.369 \\
\hline To facilitate JIT production & 8 & 2.33 & 1.159 \\
\hline
\end{tabular}

Table 3: Ranking of Reasons of not Implementing Lean

\begin{tabular}{|l|c|c|c|}
\hline \multicolumn{1}{|c|}{ Reasons } & Rank & Mean & $\begin{array}{c}\text { Std. } \\
\text { Deviation }\end{array}$ \\
\hline Unfamiliarity with lean/ JIT manufacturing & 1 & 3.66 & 1.256 \\
\hline Lack of education and expertise on lean & 2 & 3.56 & 1.562 \\
\hline Cultural barriers & 3 & 3.28 & 1.652 \\
\hline Lack of interest within the company & 4 & 2.66 & 1.698 \\
\hline Lack of senior management's interest and support & 5 & 2.37 & 1.654 \\
\hline Lack of financial resources & 6 & 2.22 & 1.952 \\
\hline Lean is not useful for the company & 7 & 2.19 & 1.244 \\
\hline It is infeasible to produce in small batches & 8 & 2.13 & 1.658 \\
\hline Lean is very complex to implement & 9 & 2.06 & 1.659 \\
\hline Lack of time & 10 & 1.90 & 1.253 \\
\hline
\end{tabular}

Nineteen performance improvement practices were extracted from extant literature, which are frequently mentioned in literature as lean practices. As shown in Table 4, among all the lean tools and programs, $5 \mathrm{~S}$ is the top-ranked lean tool applied in Indian industries with a mean value of 4.56, and a standard deviation of 1.156, followed by quality certifications and work standardization, with mean values of 4.35 and 4.19, and standard deviations of 1.125 and 0.992 , respectively. Aside from the top three tools, other widely applied, highly-ranked lean tools and programs include, for instance, visual management, continuous improvement program, statistical process control and changeover reduction (SMED). The relative high mean scores of these tools indicate that Indian industries seem to emphasize on using various lean tools to standardize, improve, and optimize internal operating procedures. Reducing wastes and costs are the obvious priorities of these firms. 
Table 4: Lean Tools and Programs Applied, all Respondents as One Group

\begin{tabular}{|l|c|c|c|}
\hline \multicolumn{1}{|c|}{ Lean practice } & Rank & Mean & $\begin{array}{c}\text { Std. } \\
\text { Deviation }\end{array}$ \\
\hline 5 S & 1 & 4.56 & 1.156 \\
\hline Quality Certification & 2 & 4.35 & 1.125 \\
\hline Work Standardization & 3 & 4.19 & 0.992 \\
\hline Visual Management & 4 & 3.92 & 1.432 \\
\hline Continuous Improvement Program & 5 & 3.75 & 1.215 \\
\hline Statistical Process Control & 6 & 3.52 & 1.365 \\
\hline Change Over Reduction(SMED) & 7 & 3.10 & 0.989 \\
\hline Cellular Layout & 8 & 2.85 & 1.421 \\
\hline Energy Management & 9 & 2.65 & 1.289 \\
\hline Error Proofing (Poka-Yoke) & 10 & 2.41 & 1.198 \\
\hline Total Productive Maintenance(TPM) & 11 & 2.22 & 1.564 \\
\hline Pull/Kanban & 12 & 1.89 & 1.234 \\
\hline PDCA Problem Solving & 13 & 1.81 & 1.248 \\
\hline Environment Management & 14 & 1.72 & 0.995 \\
\hline Just In Time & 15 & 1.59 & 1.365 \\
\hline Supplier involvement & 19 & 1.46 & 1.523 \\
\hline Benchmarking & 1.23 & 1.234 \\
\hline Supplier reduction & 1.23 & 1.234 \\
\hline Value Stream Mapping(VSM) & 1.23 & 1.234 \\
\hline
\end{tabular}

\section{CONCLUSION}

The primary objective of this paper was to enhance our understanding of adoption of lean practices in Indian industries. The study has provided important insights into the current status of lean among different industrial sectors in India. This study also provides the reasons of lean implementation in Indian industries. The Indian manufacture recommended lean due to its characteristics of quality improvement and customer satisfaction. Other reasons of lean implementation are waste elimination, decrease production costs, and increase demand management and efficiency. While utilisation of space and equipment, supply chain efficiency and JIT production received very low rating by Indian manufacturers.

This study also provides reasons of not implementing lean in Indian industries. The most strong reason to not implementing lean by Indian industry is "infeasibility to produce in small batches". In addition to that "unfamiliarity with lean/JIT manufacturing" and "lack of education and expertise on lean" are also strong reason of not implementing lean in Indian industries. 
To identify and evaluate the lean status of Indian industries, various lean tools and programs, such as Kaizen, Kanban, value stream mapping (VSM), just-in-time (JIT), visual management, cellular layout, have been included in the study. $5 \mathrm{~S}$, quality certifications and work standardization are widely used lean tool applied in Indian industries. The respondent firms were segmented into "automobiles and automobile components manufacturers", "machine tools and metal products manufacturers" and "electrical goods manufacturers", each having different sample size. It was found that in India, automobile sector has highest degree of lean implementation compared to machine tools and metal products manufacturers and electrical goods manufacturers. While electrical goods manufacturers had lowest degree of lean implementation.

\section{REFERENCES}

[1] M. Ghosh, Lean manufacturing performance in Indian manufacturing plants, Journal of Manufacturing Technology Management, 24(1), 2013, pp. 113-122.

[2] India Brand Equity Foundation, Confederation of Indian Industry, New Delhi, India http://www.ibef.org/download/Indian-Manufacturing-110512.pdf, 2012.

[3] V. Jaiganesh and J.C. Sudhahar, Sketching out the hidden lean management principles in the pharmaceutical manufacturing, International Journal of Scientific and Research Publications, 3(2), 2013, pp. 1-12.

[4] S. Poongothai and R. I. L. K. S. Arul, Total Quality Management: The Path for Continuous Quality Enhancement In Pharmaceutical Sector, Asian Journal of Biochemical and Pharmaceutical Research, 1(2), 2011, pp. 321-328.

[5] B.R. Kumar, M.K. Sharma and A. Agarwal,An experimental investigation of lean management in aviation, Journal of Manufacturing Technology Management, 26(2),2015, pp. $231-260$.

[6] G.S. Dangayach. and S.G. Deshmukh, Evidence of manufacturing strategies in Indian industry: a survey, International Journal of Production Economics, 83(3), 2003, pp. 279-798.

[7] D. Seth, N. Seth and D. Goel, Application of value stream mapping (VSM) for minimization of wastes in the processing side of supply chain of cottonseed oil industry in Indian context, Journal of Manufacturing Technology Management, 19(4),2008, pp. 529-550.

[8] M. Dogra, V.S. Sharma, A. Sachdeva and J.S. Dureja, TPM-a key strategy for productivity improvement in process industry, Journal of Engineering Science and Technology, 61, 2011, pp. 1-16.

[9] J.P. Womack, D.T. Jones, and D. Roos, The Machine That Changed the World. Rawson Associates, New York, 1990.

[10] A. Z. Keller and A. Kazazi, Just-in-time manufacturing systems: a literature review, Industrial Management \& Data Systems, 93(7), 1993, pp. 14-17.

[11] N. Oliver, R. Delbridge and J. Lowe, Lean Production Practices: International Comparisons in the Auto Components Industry, British Journal of Management, 7(s1), 1996, pp. S29-S44.

[12] J.P. Womack and D.T. Jones, Lean Thinking: Banish Waste and Create Wealth in Your Corporation, Simon and Schuster, New York, 1996. 
[13] J.K. Liker, Becoming Lean: Inside Stories of US Manufacturers, Productivity Press, Portland, 1997.

[14] S. Taj, Lean manufacturing performance in China: assessment of 65 manufacturing plants, Journal of Manufacturing Technology Management, 19(2), 2008, pp. 217-234.

[15] P. Hines, M. Holweg and N. Rich, Learning to evolve: a review of contemporary lean thinking, International Journal of Operations \& Production Management, 24(10), 2004, pp. 994-1011.

[16] R. Shah and P.T. Ward, Lean manufacturing: context, practices bundles, and performance, Journal of Operations Management, 21, 2003, pp. 129-149.

[17] G. Anand and R. Kodali, Development of a framework for lean manufacturing systems, International Journal of Services and Operations Management, 5(5), 2009, pp. 687-716.

[18] S.K. Mukhopadhyay, J. Dwivedy and A. Kumar, Design and implementation of an integrated production planning system for a pharmaceutical manufacturing concern in India, Production Planning and Control, 9(4), 1998,pp. 391-402.

[19] R.N. Roy and K.K. Guin, A proposed model of JIT purchasing in an integrated steel plant, International Journal of Production Economics, 59(1-3), 1999, pp. 179-187.

[20] V. Dhandapani, A. Potter and M. Naim, Applying lean thinking: a case study of an Indian steel plant, International Journal of Logistics Research \& Applications, 7(3), 2004, pp. 239-250.

[21] N. Upadhye, S.G. Deshmukh and S. Garg, Lean manufacturing system for medium size manufacturing enterprises: an Indian case, International Journal of Management Science and Engineering Management, 5(5), 2010, pp.362-375.

[22] S. Sharma and B. Shah, towards lean warehouse: transformation and assessment using RTD and ANP, International Journal of Productivity and Performance Management, 65(4), 2016, pp. $571-599$.

[23] S.S. Mahapatra and S.R. Mohanty, Lean manufacturing in continuous process industry: an empirical study, Journal of Scientific \& Industrial Research, 66, 2007, pp. 19-27.

[24] B. Singh, S.K. Garg and S.K. Sharma, Scope for lean implementation: a survey of 127 Indian industries, International Journal of Rapid Manufacturing, 1(3), 2010, pp. 323-333.

[25] P.B. Khadse, A.D. Sarode and R. Wasu, Lean Manufacturing in Indian Industries: A Review, International Journal of Latest Trends in Engineering and Technology, 3(1), 2013, pp. 175-181

[26] A. Panwar, R. Jain and A. P. S. Rathore, Lean implementation in Indian process industries-some empirical evidence, Journal of Manufacturing Technology Management, 26 (1), 2015,pp. 131-160.

[27] G.G. Gable, Integrating case study and survey research methods: an example in information systems", European Journal of Information Systems, 3(2), 1994, pp. 112-126. 
A Survey on the Adoption of Lean Practices in Indian Manufacturing Sector

[28] J.R.A. Santos, Cronbach's alpha: A tool for assessing the reliability of scales". Journal of extension, 37(2), 1999, pp. 1-5.

[29] B.B. Flynn, R.G. Schroeder and S. Sakakibara, A framework for quality management research and an associated measurement instrument, Journal of Operations management, 11(4), 1993, pp. 339-366.

[30] Supriya Santosh. Wagh, Prospect of Adopting Cloud Computing in Indian Manufacturing Industry. International Journal of Management (IJM), 6 (6) 2015, pp. $48-56$.

[31] J.M. Cortina, What is coefficient alpha? An examination of theory and applications, Journal of applied psychology, 78(1), 1983, pp. 98.

[32] M.Yogesh, and Dr.G.Chandramohan, Lean Manufacturing in Small and Medium Enterprises. International Journal of Mechanical Engineering and Technology (IJMET), 4 (6) 2013, pp. 64-68. 